\title{
Analisis Perusahaan Undervalue di Setiap Sektor di Pasar Saham Indonesia
}

\author{
Apta Hadyan Sulistijo ${ }^{1}$, Erman Sumirat ${ }^{2}$ \\ ${ }^{1,2)}$ Institut Teknologi Bandung, email : aptahadyan22071997@gmail.com ${ }^{1}$,erman.sumirat@sbm- \\ itb.ac.id ${ }^{2}$.
}

\section{ARTICLES INFORMATION}

\author{
ABSTRACT
}

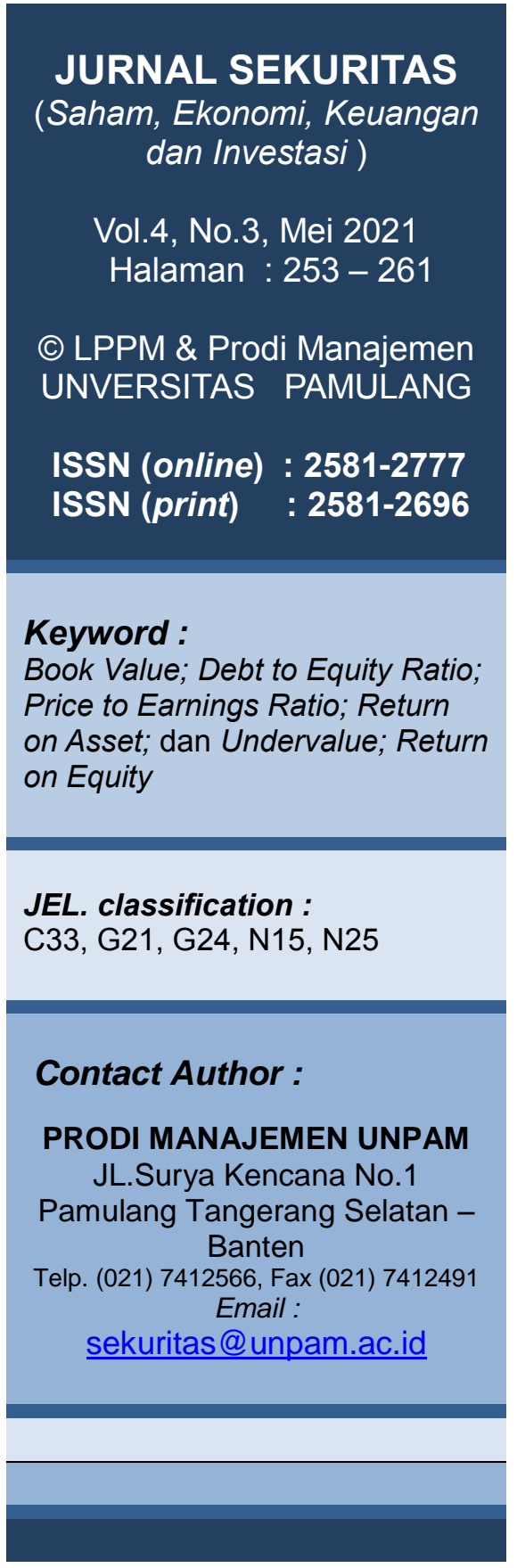

Pada dasarnya berinvestasi di pasar saham adalah membeli surat kepemilikan atas sebagian aset perusahaan. Tujuan penelitian ini untuk melakukan analisa dan mencari tahu perusahaan undervalue yang layak untuk diinvestasikan. Objek penelitian ini adalah perusahaan-perusahaan publik yang terdaftar di pasar saham Indonesia yang terkategori menjadi 11 sektor. Metode yang digunakan dalam penelitian ini adalah rasio keuangan seperti book value, return on equity, return on asset, debt to equity, dan price-to-earnings ratio. Dengan menggunakan metode rasio keuangan tersebut didapatkan hasil bahwa dari 700 perusahaan di Indonesia, hanya terdapat 5 perusahaan yang dikategorikan perusahaan undervalue dengan performa keuangan yang baik. Perusahan tersebut adalah PT. Intanwijaya International Tbk., PT Unggul Indah Cahaya Tbk., PT. Wilmar Cahaya Indonesia Tbk., PT. Provident Agro Tbk., PT. Wismilak Inti Makmur Tbk.

Basically investing in the stock market is buying a certificate of ownership of a portion of the company's assets. The purpose of this research is to analyze and find out which undervalued companies are worth investing in. The object of this research is public companies listed on the Indonesian stock market which are categorized into 11 sectors. The method used in this research is financial ratios such as book value, return on equity, return on assets, debt to equity, and price-to-earnings ratio. By using the financial ratio method, the results show that out of 700 companies in Indonesia, there are only 5 companies categorized as undervalued companies with good financial performance. The company is PT. Intanwijaya International Tbk., PT Unggul Indah Cahaya Tbk., PT. Wilmar Cahaya Indonesia Tbk., PT. Provident Agro Tbk., PT. Wismilak Inti Makmur Tbk. 


\section{A. PENDAHULUAN}

Pada dasarnya membeli lembaran saham berarti membeli atau membayar sebagian dari kepemilikan perusahaan. Harga dari perusahaan adalah yang sesuatu yang kita bayarkan sedangkan value adalah nilai yang kita dapatkan.

Di tengah kondisi resesi ekonomi akibat korona di tahun 2020, banyak perusahaan yang mengalami kesulitan keuangan dan kinerja perusahaan pun ikut terdampak. Meskipun begitu, harga-harga saham di keyatannya berbading terbalik dengan realitas sesungguhnya kinerja perusahaan. Meskipun sempat turun hingga 30\% pada bulan Maret 2020 dari bulan Januari 2020, harga saham mengalami kenaikan harga saham secara signifikan. Tabel 1 merupakan contoh beberapa perusahaan dengan kondisi rasio keuangan seperti book value dan price to earnings yang sudah sangat tinggi.

Table 1. Analisa Rasio Keuangan PT. Intanwijaya Internasional Tbk.

\begin{tabular}{ccccc}
\hline $\begin{array}{c}\text { Stock } \\
\text { Code }\end{array}$ & PBV & PER & ROE & Market Cap \\
\hline ANTM & 3.24 & 54.99 & $5.89 \%$ & $59.6 \mathrm{~T}$ \\
PGAS & 1.01 & 36.25 & $2.79 \%$ & $36.24 \mathrm{~T}$ \\
BRIS & 5.51 & 113.46 & $4.79 \%$ & $29.21 \mathrm{~T}$ \\
MCAS & 8.9 & 146 & $3.68 \%$ & $3.43 \mathrm{~T}$ \\
KAEF & 2.73 & 372.22 & $0.72 \%$ & $18.61 \mathrm{~T}$ \\
PTPP & 1.01 & 295.83 & $0.32 \%$ & $11 \mathrm{~T}$ \\
\hline
\end{tabular}

Sumber: CNBC Indonesia (2021)

Hal ini menandakan bahwasanya terkadang pasar saham tidak bisa mencerminkan dengan kondisi ekonomi sesungguhnya sehingga pendekatan untuk membeli perusahaan undervalue dengan kinerja yang baik diharapkan dapat meminimalisir resiko dari pembelian saham yang sudah terlalu mahal

Berdasarkan contoh table 1 di atas maka mengambil contoh perusahaan dengan kode saham KAEF, maka jika seorang investor menginvestasikan uangnya di perusahaan tersebut dengan cara membeli saham di perusahaan tersebut, maka investor tersebut akan membayar harga saham 2.73x lebih tinggi dari nilai buku perusahaan. Kemudian dengan kemampuan perusahaan KAEF untuk menghasilkan keuntungan bersih atau laba bersih yang dapat diatribusikan kepada entitas induk dibandingkan dengan hargab yang dibayarkan maka price to earnings rationya adalah 372.22x. Artinya investor tersebut membayar harga perusahaan dengan kode saham KAEF tersebut seharga 372 kali dari kemampuan perusahaan menghasilkan keuntungan atau jika seluruh keuntungan dibagikan kepada pemegang saham setiap 1 tahun sekali, maka investor memerlukan waktu 372 tahun untuk modal awal dia investasikan akan balik modal dengan menunggu keuntungan yang dapat dihasilkan oleh perusahaan tersebut. Karea itu salah satu metode untuk melakukan analisa kinerja keuangan perusahaan dengan menggunakan pendekatan investasi nilai atau value investing.

Pendekatan dengan menggunakan metode value investing ini adalah metode untuk membeli sebuah perusahaan dibawah nilai book valuenya dan ditahan hingga nilai harga di saham pada akhirnya kembali ke nilai book valuenya. Tetapi pendekatan ini juga memerlukan analisa dari rasio keuangan untuk mencari tau perusahaan yang undervalue dengan kinerja keuangan perusahaan yang baik dan layak untuk diinvestasikan. 
Berdasarkan uraian pendahuluan diatas maka yang menjadi masalah adalah: (1) Bagaimana cara menggunakan value investing untuk berinvestasi di pasar saham Indonesia? dan (2) Perusahaan apa saja yang undervalue dengan kinerja keuangan yang baik?

Maka dengan rumusan masalah tersebut tujuan dari penelitian ini adalah untuk menunjukkan bagaimana caranya menggunakan pendekatan value investing untuk berinvestasi di pasar saham Indonesia sehingga akan mendapatkan list perusahaan yang undervalue dengan layak untuk dipertimbankan untuk investasi.

\section{B. KAJIAN LITERATUR}

Charles Lee (Lee 2014) menyatakan value investing adalah jual beli saham dengan landasan pada perbedaan selisih antara harga pasar saat saham itu diperdagangkan dengan nilai fundamental dari sebuah perusahaan - biasanya dijelaskan dengan kata lain sebagai nilai masa kini dari ekpektasi bagi hasil yang akan didapatkan di masa depan untuk pemegang saham.

Book value (Putra 2019) adalah nilai dari modal bersih sebuah perusahaan yang dibagi dengan jumlah saham yang beredar. Sehingga penggunaan book value ini akan dapat memberikan gambaran sebuah perusahaan mahal atau murah jika dibandingkan dengan harga saham yang sedang diperdagangkan di pasar saham. Adapun rumus untuk mencari book value adalah sebagai berikut.

$$
\text { Book value }=\frac{\begin{array}{c}
\text { Jumlah ekuitas yang dapat diatribusikan } \\
\text { kepada pemilik entitas induk }
\end{array}}{\text { Jumlah saham beredar }}
$$

Price to book value (Hidayat 2019) dapat diartikan sebagai seberapa kali besar harga yang dibayarkan oleh investor untuk memperoleh sebagian aset perusahaan. Semakin tinggi price to book value maka semakin mahal harga sahamnya. Adapun rumus untuk mencari price to book value adalah sebagai berikut.

$$
\text { Price to book value }=\frac{\text { Harga saham yang diperdagangkan }}{\text { Book valu perusahaan }}
$$

Return on Equity (Gitman and Zutter 2014) untuk mengukur tingkat pengembalian yang didapatkan dihasilkan perusahaan untuk setiap dana yang diinvestasikan oleh pemegang saham biasa di perusahaan. Semakin tinggi return on equity maka semakin bagus kinerja sebuah perusahaan. Adapun rumus untuk mencari return on equity adalah sebagai berikut.

$$
\text { Return on Equity }=\frac{\begin{array}{c}
\text { Laba yang dapat diatribusikan } \\
\text { kepada entitas induk }
\end{array}}{\begin{array}{c}
\text { Jumlah ekuitas yang dapat diatribusikan } \\
\text { kepada pemilik entitas induk }
\end{array}}
$$

Return on Asset (Gitman and Zutter 2014) adalah sebuah rasio untuk mengukur seberapa besar efektifnya manajemen perusahaan untuk membukukan keuntungan dengan total aset yang dimiliki oleh perusahaan. Semakin tinggi return on asset maka semakin baik kinerja perusahaan. 


$$
\text { Return on Equity }=\frac{\begin{array}{c}
\text { Laba yang dapat diatribusikan } \\
\text { kepada entitas induk }
\end{array}}{\text { Total Asset Perusahaan }}
$$

Price to earnings ratio (Gitman and Zutter 2014) adalah rasio yang digunakan untuk mengukur seberapa banyak seorang investor tertarik untuk membayar untuk setiap rupiah yang dapat dihasilkan oleh perusahaan. Menurut (Putra 2019), semakin kecil price to earning rasio maka semakin murah sebuah perusahaan tersebut berhubungan dengan tingkat pendapatan perusahaan. Adapun rumus untuk mencari price to earnings rasio adalah sebagai berikut.

$$
\text { Price to earnings }=\frac{\text { Harga saham yang diperdagangkan }}{\text { Earning per share }}
$$

Dimana Earning per share dapat menggunakan rumus berikut.

$$
\text { Earning per share }=\frac{\begin{array}{c}
\text { Laba yang dapat diatribusikan } \\
\text { kepada entitas induk }
\end{array}}{\text { Jumlah saham beredar }}
$$

Debt to Equity (Filbert 2019) adalah rasio seberapa besar perbandingan antara total liabilitas yang dimiliki perusahaan dibandingkan dengan modal kerja atau ekuitas perusahaan.

$$
\text { Debt to Equity }=\frac{\text { Total Liabilitas }}{\begin{array}{c}
\text { Jumlah ekuitas yang dapat diatribusikan } \\
\text { kepada pemilik entitas induk }
\end{array}}
$$

\section{METODOLOGI PENELITIAN}

Metode penelitian yang digunakan dalam penelitian ini adalah metode rasio keuangan untuk melakukan analisa dan penilaian dari perusahaan undervalue yang ada di pasar saham Indonesia. Rasio keuangan yang akan digunakan di sini adalah book value, debt to equity ratio, price to earnings ratio, return on asset, dan return on equity. Adapun untuk kirteria dari price to book value adalah $<1$, debt to equity $<1$, return on equity $>10 \%$, price to earnings ratio $<10$.

Data yang digunakan dalam penelitian ini menggunakan data yang berdasarkan dari data sekunder yakni dari data laporan keuangan yang diterbitkan oleh perusahaan dengan menggunakan data yang disetahunkan untuk data laporan keuangan quartal 32020.

\section{HASIL DAN PEMBAHASAN}

Hasil dari penelitian ini dengan menggunakan rasio keuangan seperti yang telah disebutkan pada bab sebelumnya. Didapatkan total terdapat 5 perusahaan yang terpilih dengan kondisi perusahaan yang undervalue dan dengan performa kinerja yang baik. 5 perusahaan tersebut adalah PT. Intanwijaya International Tbk. (sub-industry basic chemicals), PT. Unggul Indah Cahaya Tbk. (sub-industry basic chemicals), PT. Wilmar Cahaya Indonesia Tbk. (sub-industry processed foods), PT. Provident Agro Tbk. (subindustry plantation \& crops), dan PT. Wismilak Inti Makmur Tbk. (sub-industry tobacco).

Pertama, PT. Intanwijaya International Tbk. (INCI) berdasarkan data yang dirilis dari laporan keuangan quartal 3 2020, didapatkan baha PT. Intan wijaya international Tbk. 
memiliki jumlah saham beredar sebanyak 0,2 miliar lembar saham dan ekuitas yang dapat didistribusikan kepada pemegang induk adalah Rp.368 Miliar. Sehingga didapatkan Book valuenya adalah Rp.1879/saham. Dibandingkan dengan harga sahamnya diperdagangkan pada harga Rp.825/saham maka price to book value PT. Intan Wijaya Internasional Tbk. adalah $0.4 \mathrm{x}(<1)$. Kemudian dilihat dari data laba bersih yang bisa diatribusikan kepada pemilik entitas induk perusahaan sebesar Rp. 31 Miliar, maka return on equitynya adalah $11 \%(>10 \%)$. Perbandingan antara harga saham diperjualbelikan dengan keuntungan per lembar saham perusahaan maka didapatkan price to earnings rasio nya adalah $2.9 \times(<10)$ dan dengan liabilitas sebanyak Rp.69 Miliar, maka rasio debt-to-equity rasio perusahaan ini adalah $0.2(<1)$. Sehingga PT. Intanwijaya Internasional Tbk. (INCI), termasuk ke dalam kategori investasi undervalue yang layak dipertimbangkan untuk diinvestasi. Tabel 2 adalah rasio keuangan PT. Intanwijaya Internasional Tbk dari tahun 2015 hingga tahun 2020.

Table 2. Analisa Rasio Keuangan PT. Intanwijaya Internasional Tbk.

\begin{tabular}{ccccccc}
\hline Keterangan & \multicolumn{7}{c}{ Year } \\
\cline { 2 - 7 } & $\mathbf{2 0 1 5}$ & $\mathbf{2 0 1 6}$ & $\mathbf{2 0 1 7}$ & $\mathbf{2 0 1 8}$ & $\mathbf{2 0 1 9}$ & $\mathbf{2 0 2 0 ^ { * }}$ \\
\hline Jumlah saham beredar (Milliar) & 0.2 & 0.2 & 0.2 & 0.2 & 0.2 & 0.2 \\
Ekuitas (Milliar) & 154 & 243 & 267 & 318 & 332 & 368 \\
Liabilitas (Milliar) & 15 & 27 & 35 & 71 & 71 & 69 \\
Laba Bersih (Milliar) & 17 & 10 & 17 & 17 & 14 & 31 \\
Harga per Lembar saham & 305 & 306 & 408 & 575 & 374 & 825 \\
Book Value (Milliar) & 770 & 1214 & 1334 & 1591 & 1662 & 1842 \\
PBV (X) & 0.4 & 0.3 & 0.3 & 0.4 & 0.2 & 0.4 \\
Return on Equity (\%) & 11 & 4 & 6 & 5 & 4 & 11 \\
Price to Earnings (X) & 3.6 & 6.1 & 4.9 & 6.9 & 5.4 & 3.9 \\
Debt to Equity (X) & 0.1 & 0.1 & 0.1 & 0.2 & 0.2 & 0.2 \\
\hline
\end{tabular}

Sumber: Laporan Keuangan PT. Intanwijaya Internasional Tbk. (2015-2020)

Kedua, PT. Unggul Indah Cahaya Tbk. (UNIC) berdasarkan data laporan keuangan quartal 3 2020, perusahaan memiliki jumlah saham yang beredar sebanyak 0.4 Miliar lembar saham dengan ekuitas perusahaan sebesar Rp.2,578 Miliar, maka perusahaan memiliki book value sebesar Rp.6724/saham. Dibandingkan dengan harga saham yang diperdagangkan di harga Rp.4810/saham, maka price to book value adalah adalah $0.7 \mathrm{x}$ $(<1)$. Perusahaan berdasarkan kinerja laporan keuangan mencetak laba bersih sebesar Rp.200 Miliar. Sehingga return on equity adalah 10.3\% (>10\%). Laba perusahaan ini dibandingkan dengan harga saham diperjualbelikan maka didapatkan rasio price to earnings adalah $5.2(<10)$ dan dengan liabilitas sebanyak Rp.574 miliar, maka debt to equity adalah $0.2 x(<1)$. Sehingga PT. Unggul Indah Cahaya Tbk. (UNIC) adalah perusahaan undervalue yang layak dipertimbangkan untuk diinvestasi. Berikut tabel 3 adalah kinerja rasio keuangan PT. Unggul Indah Cahaya Tbk dari tahun 2015 hingga tahun 2020.

Table 3. Analisa Rasio Keuangan PT. Unggul Indah Cahaya Tbk.

\begin{tabular}{ccccccc}
\hline \multirow{2}{*}{ Keterangan } & \multicolumn{7}{c}{ Year } \\
\cline { 2 - 7 } & $\mathbf{2 0 1 5}$ & $\mathbf{2 0 1 6}$ & $\mathbf{2 0 1 7}$ & $\mathbf{2 0 1 8}$ & $\mathbf{2 0 1 9}$ & $\mathbf{2 0 2 0 ^ { * }}$ \\
\hline Jumlah saham beredar (Milliar) & 0.4 & 0.4 & 0.4 & 0.4 & 0.4 & 0.4 \\
Ekuitas (Milliar) & 1904 & 2172 & 2066 & 2663 & 2325 & 2578 \\
Liabilitas (Milliar) & 1104 & 888 & 883 & 1008 & 605 & 574 \\
Laba Bersih (Milliar) & -12 & 309 & 170 & 249 & 170 & 200 \\
Harga per Lembar saham & 1408 & 2160 & 3420 & 3900 & 3100 & 4810
\end{tabular}




\begin{tabular}{ccccccc}
\hline Keterangan & \multicolumn{7}{c}{ Year } \\
\cline { 2 - 7 } & $\mathbf{2 0 1 5}$ & $\mathbf{2 0 1 6}$ & $\mathbf{2 0 1 7}$ & $\mathbf{2 0 1 8}$ & $\mathbf{2 0 1 9}$ & $\mathbf{2 0 2 0}$ \\
\hline Book Value (Milliar) & 4966 & 5666 & 5388 & 5904 & 6066 & 6724 \\
PBV (X) & 0.3 & 0.4 & 0.6 & 0.7 & 0.5 & 0.7 \\
Return on Equity (\%) & -1 & 14 & 8 & 11 & 7 & 10 \\
Price to Earnings (X) & - & 2.7 & 7.7 & 6.0 & 7.0 & 6.9 \\
Debt to Equity (X) & 0.6 & 0.4 & 0.4 & 0.4 & 0.3 & 0.2
\end{tabular}

Sumber: Laporan Keuangan PT. Unggul Indah Cahaya Tbk (2015-2020)

Ketiga, PT. Wilmar Cahaya Indonesia Tbk. (CEKA) berdasarkan data laporan keuangan quartal 3 2020, perusahaan memiliki jumlah saham beredar sebanyak 0.6 miliar lembar saham. Sedangkan perusahaan memiliki jumlah ekuitas sebanyak Rp.1187 miliar sehingga didapatkan book value sebesar Rp.1995/saham. Dibandingkan dengan harga saham perusahaan diperjualbelikan diharga Rp. 1750/saham maka price to book value adalah 0.9 $(<1)$. Kemampuan perusahaan dalam mencetak laba bersih adalah sebesar RP.115 milliar sehingga return on equity perusahaan adalah $13 \%(>10 \%)$. Maka rasio dari price to earnings adalah $6.8(<10)$. Serta perusahaan memiliki total liabilitas sebesar Rp.198 miliar jika dibandingkan dengan ekuitas perusahaan maka debt to equity perusahaan adalah $0.2(<1)$. Maka PT. Wilmar Cahaya Indonesia Tbk. (CEKA) layak untuk dipertimbangkan untuk investasi. Berikut tabel 4 adalah kinerja rasio keuangan perusahaan PT. Wilmar Cahaya Indonesia Tbk. dari tahun 2015 hingga tahun 2020.

Table 4. Analisa Rasio Keuangan PT. Wilmar Cahaya Indonesia Tbk.

\begin{tabular}{ccccccc}
\hline Keterangan & \multicolumn{7}{c}{ Year } \\
\cline { 2 - 7 } & $\mathbf{2 0 1 5}$ & $\mathbf{2 0 1 6}$ & $\mathbf{2 0 1 7}$ & $\mathbf{2 0 1 8}$ & $\mathbf{2 0 1 9}$ & $\mathbf{2 0 2 0 ^ { * }}$ \\
\hline Jumlah saham beredar (Milliar) & 0.6 & 0.6 & 0.6 & 0.6 & 0.6 & 0.6 \\
Ekuitas (Milliar) & 640 & 888 & 903 & 977 & 1131 & 1187 \\
Liabilitas (Milliar) & 846 & 538 & 490 & 192 & 262 & 198 \\
Laba Bersih (Milliar) & 107 & 250 & 107 & 93 & 215 & 115 \\
Harga per Lembar saham & 1375 & 1295 & 1350 & 1000 & 1690 & 1750 \\
Book Value (Milliar) & 1075 & 1492 & 1518 & 1641 & 1901 & 1995 \\
PBV (X) & 1.3 & 0.9 & 0.9 & 0.6 & 0.9 & 0.9 \\
Return on Equity (\%) & 17 & 28 & 12 & 9 & 19 & 13 \\
Price to Earnings (X) & 7.7 & 3.1 & 7.5 & 6.4 & 4.7 & 6.8 \\
Debt to Equity (X) & 1.3 & 0.6 & 0.5 & 0.2 & 0.2 & 0.2 \\
\hline
\end{tabular}

Sumber: Laporan Keuangan PT. Wilmar Cahaya Indonesia Tbk (2015 - 2020)

Keempat, PT. Provident Agro Tbk. (PALM) berdasarkan data laporan keuangan quartal 3 2020, perusahaan memiliki 7.12 miliar lembar saham. Perusahaan memiliki ekuitas sebesar Rp.2957 miliar. Sehingga jika ekuitas dibandingkan dengan lembar saham yang beredar, maka akan didapatkan nilai book value dari perusahaan adalah Rp. 415/saham. Jika dibandingkand dengan harga saham diperdagangkan di harga Rp.348/saham maka price to book value perusahaan adalah $0.8(<1)$. Kinerja perusahaan dalam mencetak laba bersih sangat baik dengan per kuartal 3 2020, dapat mencetak laba bersih sebesar Rp.237 Milliar. Maka return on equity perusahaan adalah sebesar $11 \%(>10 \%)$. Keuntungan laba bersih ini dibandingkan dengan harga perusahaan diperdagangkan maka didapatkan price to earnings sebesar $5.9(<10)$. Perusahaan memiliki total liabilitas sebesar Rp.200 Miliar, maka perbandingan rasio antara total liabilitas dengan ekuitas perusahaan atau debt to equity adalah 0.1. Maka dengan kondisi berikut PT. Provident Agro Tbk. (PALM), layak untuk 
dipertimbangkan untuk investasi. Tabel 5 adalah rasio keuangan PT. Provident Agro Tbk. dari tahun 2015 hingga tahun 2020.

Table 5. Analisa Rasio Keuangan PT. Provident Agro Tbk.

\begin{tabular}{ccccccc}
\hline \multirow{2}{*}{ Keterangan } & \multicolumn{7}{c}{ Year } \\
\cline { 2 - 7 } & $\mathbf{2 0 1 5}$ & $\mathbf{2 0 1 6}$ & $\mathbf{2 0 1 7}$ & $\mathbf{2 0 1 8}$ & $\mathbf{2 0 1 9}$ & $\mathbf{2 0 2 0 ^ { * }}$ \\
\hline Jumlah saham beredar (Milliar) & 7.1 & 7.1 & 7.1 & 7.1 & 7.1 & 7.1 \\
Ekuitas (Milliar) & 1686 & 2325 & 1562 & 1612 & 2067 & 2957 \\
Liabilitas (Milliar) & 3010 & 1534 & 1309 & 380 & 263 & 200 \\
Laba Bersih (Milliar) & -55 & 219 & 66 & -111 & -71 & 237 \\
Harga per Lembar saham & 425 & 456 & 328 & 260 & 208 & 348 \\
Book Value (Milliar) & 237 & 327 & 219 & 226 & 290 & 415 \\
PBV (X) & 1.8 & 1.4 & 1.5 & 1.1 & 0.7 & 0.8 \\
Return on Equity (\%) & -3 & 9 & 4 & -7 & -3 & 11 \\
Price to Earnings (X) & - & 14.8 & 35.4 & - & - & 7.9 \\
Debt to Equity (X) & 1.8 & 0.7 & 0.8 & 0.2 & 0.1 & 0.1 \\
\hline
\end{tabular}

Sumber: Laporan Keuangan PT. Provident Agro Tbk (2015-2020)

Kelima, PT. Wismilak Inti Makmur Tbk. (WIIM) berdasarkan data yang dirilis dari laporan keuangan quartal 32020 , perusahaan memiliki jumlah saham yang beredar sebanyak 2.1 miliar lembar saham. Berdasarkan laporan keuangan, nilai ekuitas perusahaan adalah sebesar Rp.1124 miliar berarti jika dibandingkan dengan jumlah saham yang beredar, maka perusahaan memiliki book value sebesar Rp.535/saham. Dibandingkan dengan harga di pasar saat ini diperdagangkan di harga Rp. 550/saham, maka price to book value adalah 1. Melihat kinerja perusahaan dalam mencetak laba bersih sepanjang tahun hingga quartal 3 2020, perusahaan mampu mencetak laba bersih sebesar Rp.109 Miliar, hal ini membuat kinerja perusahaan dalam mencetak laba return on equity sebesar $13 \%(>10 \%)$. maka jika harga yang diperdagangkan dibandingkan dengan laba bersih maka didapatkan rasio price to earnings sebesar $6(<10)$. Dapat dilihat pula total liabilitas perusahaan adalah sebesar Rp.428 Miliar maka perbandingan total liabilitas dengan ekuitas perusahaan adalah $0.4(<1)$. Maka dengan pertimbangan berikut, saham PT. Wismilak Inti Makmur Tbk. (WIIM), layak untuk dipertimbangkan untuk investasi. Tabel 6 adalah rasio keuangan PT. Wismilak Inti Makmur Tbk dari tahun 2015 hingga tahun 2020.

Table 6. Analisa Rasio Keuangan PT. Wismilak Inti Makmur Tbk.

\begin{tabular}{ccccccc}
\hline \multirow{2}{*}{ Keterangan } & $\mathbf{7}$ Year \\
\cline { 2 - 7 } & $\mathbf{2 0 1 5}$ & $\mathbf{2 0 1 6}$ & $\mathbf{2 0 1 7}$ & $\mathbf{2 0 1 8}$ & $\mathbf{2 0 1 9}$ & $\mathbf{2 0 2 0}$ \\
\hline Jumlah saham beredar (Milliar) & 2.1 & 2.1 & 2.1 & 2.1 & 2.1 & 2.1 \\
Ekuitas (Milliar) & 943 & 990 & 997 & 1004 & 1032 & 1124 \\
Liabilitas (Milliar) & 399 & 363 & 248 & 250 & 266 & 428 \\
Laba Bersih (Milliar) & 131 & 106 & 41 & 51 & 27 & 109 \\
Harga per Lembar saham & 430 & 440 & 290 & 141 & 168 & 550 \\
Book Value (Milliar) & 449 & 471 & 465 & 478 & 491 & 535 \\
PBV (X) & 1.0 & 0.9 & 0.6 & 0.3 & 0.3 & 1.0
\end{tabular}




\begin{tabular}{cccccccc}
\hline Keterangan & \multicolumn{7}{c}{ Year } \\
\cline { 2 - 7 } & $\mathbf{2 0 1 5}$ & $\mathbf{2 0 1 6}$ & $\mathbf{2 0 1 7}$ & $\mathbf{2 0 1 8}$ & $\mathbf{2 0 1 9}$ & $\mathbf{2 0 2 0}$ \\
\hline Return on Equity $(\%)$ & 14 & 11 & 4 & 5 & 3 & 13 \\
Price to Earnings $(X)$ & 6.9 & 8.7 & 15.0 & 5.8 & 12.9 & 8.0 \\
Debt to Equity $(X)$ & 0.4 & 0.4 & 0.3 & 0.2 & 0.3 & 0.4 \\
\hline
\end{tabular}

Sumber: Laporan Keuangan PT. Wismilak Inti Makmur Tbk (2015 - 2020)

Sehingga table 6 berikut merupakan gabungan dari kelima perusahaan yang terkategorikan undervalue dengan kinerja keuangan yang baik sehingga kelima perusahaan ini layak untuk dipertimbangkan untuk berinvestasi.

Table 7. Rangkuman Hasil Analisa Rasio Keuangan

\begin{tabular}{ccccccccccc}
\hline $\begin{array}{c}\text { Kode } \\
\text { Saham }\end{array}$ & $\begin{array}{c}\text { Jumlah } \\
\text { lembar } \\
\text { saham }\end{array}$ & Ekuitas & Liabilitas & $\begin{array}{c}\text { Laba } \\
\text { Bersih }\end{array}$ & $\begin{array}{c}\text { Harga } \\
\text { saham }\end{array}$ & $\begin{array}{c}\text { Book } \\
\text { Value }\end{array}$ & PBV & ROE & PER & DER \\
\hline INCI & 0.2 & 368 & 69 & 31 & 825 & 1879 & 0.4 & $11 \%$ & 2.9 & 0.2 \\
\hline UNIC & 0.4 & 2578 & 574 & 200 & 4810 & 6724 & 0.7 & $10.3 \%$ & 5.2 & 0.2 \\
\hline CEKA & 0.6 & 1187 & 198 & 115 & 1750 & 1995 & 0.9 & $13 \%$ & 6.8 & 0.2 \\
\hline PALM & 7.12 & 2957 & 200 & 237 & 348 & 415 & 0.8 & $11 \%$ & 5.9 & 0.1 \\
\hline WIIM & 2.10 & 1124 & 428 & 109 & 550 & 535 & 1 & $13 \%$ & 6 & 0.4 \\
\hline
\end{tabular}

Berdasarkan hasil rangkuman data dari tabel 7, maka perusahaan dengan rasio price to book value paling kecil adalah perusahaan INCI dengan PBV 0.4, ROE 11\%, dan PER 2.9. sedangkan untuk perusahaan dengan harga yang terbilang mahal bisa dimasukkan adalah perusahaan dengan kode saham WIIM. WIIM memiliki price to book value sama dengan satu, return on equity $13 \%$, dan price to earnings adalah 6 .

Jika dilihat perbandingan dengan price to book value paling terkecil maka perusahaan PT. Intanwijaya Internasional menempati urutan pertama dengan PBV sebesar 0.4. Untuk kategori perusahaan dengan kinerja kemampuan perusahaan untuk dapat menghasilkan keuntungan, maka ada dua perusahaan yang memiliki return on equity sama yakni perusahaan PT. Wilmar Cahaya Indonesia, dan PT. Wismilak Inti Makmur dengan kedua perusahaan tersebut memiliki ROE sebesar $13 \%$. Sedangkan untuk perbandingan antara harga per lembar saham yang dibayarkan investor dengan pendapatan bersih per lembar saham yang bisa didapatkan investor maka rasio price to earnings yang paling kecil adalah perusahaan PT. Intanwijaya Internasional dengan PER sebesar 2.9.

Oleh sebab itu, dengan berdasarkan hasli analisa tersebut jika investor melakukan pembelian saham perusahaan PT. Intanwijaya Internasional Tbk., dengan kondisi harga sekarang di Rp.825/saham dan menunggu hingga kembali ke nilai book valuenya sebesar Rp.1879/saham maka investor akan mendapatkan persentase keuntungan sebesar $127 \%$.

\section{E. KESIMPULAN}

Berdasarkan hasil yang didapatkan, maka dengan menganalisa menggunakan pendekatan value investing dan rasio keuangan dari 700 perusahaan yang terdaftar di pasar saham Indonesia, maka hanya 5 perusahaan saja yang termasuk kategori undervalue dengan kinerja keuangan yang baik. Metode value investing digunakan dengan rasio keuangan dengan menggunakan data yang bersumber dari laporan keuangan perusahaan sehingga didapatkan rasio-rasio keuangan yang menggambarkan kinerja performa dari perusahaan. Adapun 5 perusahaan yang terpilih untuk layak dijadikan pertimbangan untuk 
investasi adalah PT. Intanwijaya International Tbk., PT. Unggul Indah Cahaya Tbk., PT. Wilmar Cahaya Indonesia Tbk., PT. Provident Agro Tbk., dan PT. Wismilak Inti Makmur Tbk.

Adapun saran dan masukan dalam penelitian ini adalah potensi untuk mendapatkan keuntungan dalam pasar saham dengan menggunakan metode value investing akan jauh lebih besar jika mempertimbangkan pula dengan kondisi sektoral di mana perusahaan itu berada sehingga dengan memanfaatkan kombinasi antara perusahaan undervalued dan potensi siklus bisnis yang akan bergerak naik akan memaksimalkan keuntungan. Sehinnga untuk penelitian selanjutnya dengan memasukkan faktor kondisi siklus bisnis bisa menjadi pertimbangan untuk memilih saham undervalued yang akan menciptakan profitabilitas yang baik ketika siklus bisnisnya mendukung.

\section{DAFTAR PUSTAKA}

Filbert, Ryan. 2019. Investasi Saham Ala Fundamentalis Dunia. Seventh. Jakarta: PT. Elex Media Computindo.

Gitman, Lawrence J., and Chad J. Zutter. 2014. Principles of Managerial Finance. 14th ed. edited by D. Battista. Harlow: Pearson.

Hidayat, Teguh. 2019. Value Investing Beat the Market in Five Minutes. seventh. Jakarta: PT Elex Media Komputindo.

Husain, T., \& Sunardi, N. (2020). Firm's Value Prediction Based on Profitability Ratios and Dividend Policy. Finance \& Economics Review, 2(2), 13-26.

Kadim, A., Sunardi, N \& Husain, T. (2020). The modeling firm's value based on financial ratios, intellectual capital and dividend policy.Accounting, 6(5), 859-870

Lee, Charles M. C. 2014. "Value Investing: Bridging Theory and Practice." China Accounting and Finance Review 16(Fundamental Analysis of Accounting Information-Comparative Studies between the Chinese and US Capital Markets):10. doi: 10.7603/s40570-0140005-3.

PT. Intanwijaya Internasional Tbk. 2020. Laporan Keuangan Kuartal 32020 PT. Intanwijaya Internasional Tbk. Jakarta.

PT. Unggul Indah Cahaya Tbk. 2020. Laporan Keuangan Kuartal 32020 PT. Unggul Indah Cahaya Tbk. Jakarta.

PT. Wilmar Cahaya Indonesia Tbk. 2020. Laporan Keuangan Kuartal 32020 PT. Wilmar Cahaya Indonesia Tbk. Jakarta.

PT. Wismilak Inti Makmur Tbk. 2020. Laporan Keuangan Kuartal 32020 PT. Wismilak Inti Makmur Tbk. Jakarta.

Putra, Andika Sutoro. 2019. Anak Muda Miliarder Saham. 6th ed. edited by W. Yoevestian. Jakarta: PT Elex Media Komputindo.Tbk., PT. Provident Agro. 2020. Laporan Keuangan Kuartal 32020 PT. Provident Agro Tbk. Jakarta.

Sunardi, N. (2019). Profitabilitas, Likuiditas, Dan Multiplier Equity Pengaruhnya Terhadap Harga Serta Return Saham Pada Industri Manufaktur Tahun 2012-2017. Inovasi, 6(1), 58-73.

Sunardi, N. (2019). Relevansi Intelectual Capital terhadap Harga dan Retun Saham di Industri Perbankan Pemerintah di Indonesia. JIMF (Jurnal IImiah Manajemen Forkamma), 3(1). 